\title{
Millennials Interest in Fabric Masks in Covid-19 Era
}

\author{
Marniati ${ }^{1}{ }^{*}$, Dewi Lutfiati ${ }^{1 \mathrm{~b}}$, Arita Puspitorini ${ }^{1 \mathrm{c}}$ and Peppy Mayasari ${ }^{1, \mathrm{~d}}$ \\ 1Department of Home Economics Education, Faculty of Engineering, Universitas Negeri Surabaya, Surabaya, \\ Indonesia \\ a marniati@unesa.ac.id; b diwelitfiati@unesa.ac.id; c aritapuspitorini@unesa.ac.id, d peppymayasari@unesa.ac.id \\ *Corresponding Author : marniati@unesa.ac.id | Phone : 08121658356
}

\begin{abstract}
This study aims to measure the interest of a group of young people in the use of fabric masks in the Covid-19 era in terms of the value of needs, designs, colors, types of materials, and accessories. This study uses a quantitative approach. The research subjects were all new students of 2020, the Department of Home Economics Education with a sample of 228. The data collection method used a questionnaire with a Likert scale model of four alternative answers. The data analysis technique used descriptive analysis of the frequency distribution and exploratory factor analysis. The instrument validity was proven by Product Moment Correlation, while its reliability was tested by Cronbach's Alpha. The results showed that the mask design was more explained by colors, materials, and fashionable factors, while mask values were due to consideration of needs and protection factors.
\end{abstract}

Keywords: Covid-19; Fabric masks; Millennials;

\section{Introduction}

International response to the spread of Covid-19 in Indonesia is to immediately declare a national emergency, educate the public and communicate actively by implementing appropriate risk communication, and further improve the community, more intensively trace positive cases of Covid-19, carry out laboratory decentralization so that the response team can map the cluster and distribution, and can share detailed data about the approach taken by Indonesia and the government's steps in conducting surveillance and examinations, including patient contact identification data and a summary of Covid-19 patient contact tracing data.

As a response to the corona virus pandemic, several universities throughout Indonesia chose to cancel classes and replace them with online learning, but in anticipation of post-pandemic students will still be present at the campus to continue their studies. The post-pandemic period will certainly continue to be aware of the spread of the corona virus, which until now there is no antidote.

The reality that has happened so far is that there is a lot of assistance that focuses on the treatment process after being exposed to Covid-19. Supposedly if the principle of prevention and cure is improved and a priority. So it is necessary to make an effort in any form so that the spread of this outbreak can be controlled. One of the efforts that can be made to prevent the spread of Covid-19 is by increasing self-care by using masks, where the use of masks is very important during this pandemic, masks that play a role in protecting the body from the spread of the corona virus through droplets from one person to another or local society.

According to Herman (2016) the use of fabric masks is an effective way to maintain a minimum distance of one meter and use masks and to protect oneself from various threats and dangers, such as: dust and various infectious disease outbreaks. This is the best way and alternative to reduce the risk of infection and to take early prevention from Covid-19 as it is today. The use of masks if done correctly, masks will still be able to reduce the spread of the Corona virus in the community, especially from people who are infected with the virus but have no symptoms. Thus, you also have to reduce activities by reducing activities in a place where there are enough people, it would be nice to keep doing physical distancing even though you have worn a fabric mask. This is especially so for those millennials whose activities are quite dynamic.

Many people think, the millennial generation and generation $\mathrm{Z}$ or what is popularly called "kids 
nowadays". The term 'kids nowadays' is given to generation Z or the generation born between 1995-2013. Only sometimes it is often confused which is the millennial generation, which is the $\mathrm{Z}$ generation. From a small portion of Generation $Y$ and most of Generation X, then a new generation was born called Generation $Z$. This generation, born in the mid-1990s to mid-2000s, was born. more familiar with technologies. The skills that must be possessed at this time in facing the Challenges of the Age for this generation are: (1) foreign language, (2) public speaking, (3) operating computers. Operating Microsoft. Operate software to design images and programming language. (4) writing, (5) networking, (6) smart in appearance. These six things are inherent in the students.

Based on the description above, this research was conducted to determine Millennials interest in fabric masks (non-medical) in the Covid-19 era in terms of the value of needs, designs, colors, types of materials, and accessories in fabric masks. As an effort to protect the nation's assets early. On the other hand, this is an effort to prevent and break the chain of transmission of the Covid-19 virus that is currently engulfing Indonesia.

\section{Materials and Methods}

\subsection{Research Subjects Determination}

The research was conducted at the State University of Surabaya at the beginning of the odd semester of 2020/2021 with a quantitative approach. The research subjects were all new students in the Home Economics Education major for the academic year 2020, 427 people in total. The research sample was 228 and the sample was taken by proportional random sampling. Data collection techniques using instruments through a Likert scale survey which consists of four alternative answers. Using google form.

\subsection{Statistical Data Analysis}

The data analysis technique used descriptive analysis of the frequency distribution and exploratory factor analysis. The validity of the instrument is proven by Product Moment Correlation, while its reliability is tested by Cronbach's Alpha.

\section{Results And Discussions}

\subsection{Research Variables Description}

Two variables in this study, namely mask values and mask design were measured using 4 items. Respondents' answers descriptions to these two variables are displayed using the proportion of the frequency distribution of answers 1 or 2 to represent negative responses and answer 3 or 4 to represent positive responses.

Table 1. Research Variables Description

\begin{tabular}{|c|c|c|c|}
\hline Variables & Item Description & $\begin{array}{c}\text { Negative } \\
\text { Response } \\
(\%)\end{array}$ & $\begin{array}{c}\text { Positive } \\
\text { Response } \\
(\%)\end{array}$ \\
\hline \multicolumn{4}{|l|}{ Value Needs } \\
\hline & $\begin{array}{l}\text { In the Covid-19 pandemic era which has plagued from February } 2020 \text { to the } \\
\text { present, the need for masks is the main thing. }\end{array}$ & 0.4 & 99.6 \\
\hline & $\begin{array}{l}\text { In the current Covid-19 pandemic era, I like to wear a mask when leaving the } \\
\text { house. }\end{array}$ & 1.8 & 98.2 \\
\hline & As a Milleninial, I have to wear a mask, to maintain my and others health. & 14.5 & 85.5 \\
\hline & I prefer mask made by fabric because they are comfortable to wear. & 1.8 & 98.2 \\
\hline \multicolumn{4}{|l|}{ Desain } \\
\hline & I love fashionable and attractive masks. & 41.7 & 58.3 \\
\hline & I really like bright colored masks that fit my youth and characters. & 13.6 & 86.4 \\
\hline & $\begin{array}{l}\text { I prefer cotton as mask materials, besides being comfortable to use, it also } \\
\text { absorbs sweat/is hygroscopic. }\end{array}$ & 15.4 & 84.6 \\
\hline & Mask with accessories add to my confidence and suit my taste. & 96.1 & 3.9 \\
\hline
\end{tabular}

Mask as a tool that Masks as a tool that is one of the necessities during the Covid-19 pandemic tend to be responded positively by students. Masks at this time require many people (99.6\%), are accustomed to using masks when leaving the house $(98.2 \%)$ and prefer masks made of cotton fabric. The response that 
masks can be used to maintain personal health and other people has the highest negative response (14.5\%).

The masks that were too fashionable were not liked by many young people $(41.7 \%)$. Masks designed with bright colors and using cotton received high positive responses (84.6-86.4\%). At this time, masks with certain accessories were not liked by most students, only 3.9\% responded positively where some of these groups felt they could be more confident when wearing masks.

The questionnaire instrument used in this study, its validity and reliability were checked using the corrected correlation coefficient in the validity section and the Cronbach Alpha coefficient to measure the reliability of the instrument. In the mask values instrument, the correlation coefficient ranges from 0.351 to 0.430 with a value greater than 0.30 indicating good validity. And the Cronbach's Alpha coefficient of 0.601 which has exceeded 0.60 also explains the acceptable consistency.

Table 2. Item Validity and Reliability

\begin{tabular}{llccc}
\hline Variables & Item & $\begin{array}{c}\text { Corrected Item-Total } \\
\text { Correlation }\end{array}$ & $\begin{array}{c}\text { Cronbach's Alpha if Item } \\
\text { Deleted }\end{array}$ & $\begin{array}{c}\text { Cronbach's Alpha } \\
\text { Reliability Coefficient }\end{array}$ \\
\hline Mask Values & Needs & 0.407 & 0.527 & 0.601 \\
\hline & Protection & 0.351 & 0.558 & \\
\hline Health & 0.393 & 0.523 & \\
\hline Mask Design & Passions & 0.430 & 0.505 & 0.754 \\
\hline & Fashionable & 0.463 & 0.776 & \\
\hline & Colors & 0.740 & 0.594 & \\
\hline
\end{tabular}

The instrument of mask value, the correlation coefficient ranging from 0.328 to 0.757 is greater than 0.30 indicating good validity. And the Cronbach's Alpha coefficient of 0.754 which has exceeded 0.60 also explains the acceptable consistency. So it can be concluded that the instrument in this study is suitable for use.

\subsection{Mask Values Factor Analysis}

The value of masks is explained by 4 items, namely masks are one of the main needs in this pandemic (necessity), people prefer to use masks when leaving the house (protection), masks for personal health and others (health), and fabric masks are preferred because comfortable to wear (favorite). Exploratory factor analysis is used to determine data structures that can explain considerations in assessing the position of masks for today's society. The application of this factor analysis requires dependencies between items that are determined using the Kaiser Myer Olkin (KMO) value and the Measure of Sampling Adequacy (MSA). Dependency is high if KMO and MSA are more than 0.50 .

Table 3. Dependency Descriptions Between Mask Values Items

\begin{tabular}{lll}
\hline tem & Mean & MSA \\
\hline Needs & 3.73 & 0.523 \\
\hline Protection & 3.76 & 0.511 \\
\hline Health & 3.12 & 0.514 \\
\hline Passions & 3.00 & 0.547 \\
\hline
\end{tabular}

$\mathrm{KMO}=0.522$

The KMO value is 0.522 (more than 0.50) and the MSA is in the range 0.511-0.547 (more than 0.50), which explains that the item dependency requirements are acceptable. Furthermore, extraction is carried out into several components where the contribution of each attribute is explained by the size of the factor loading.

Table 4. Mask Value Item Extraction

\begin{tabular}{ccc}
\hline & \multicolumn{2}{c}{ Component } \\
\cline { 2 - 3 } Items & 1 & 2 \\
\hline Needs & 0.924 & 0.043 \\
\hline Protection & 0.913 & 0.112 \\
\hline Health & 0.026 & 0.877 \\
\hline Passions & 0.121 & 0.859 \\
\hline Eigen Value & 1.895 & 1.328 \\
\hline$\%$ Total Variant & $47.383 \%$ & $33.197 \%$ \\
\hline Total Variant Cumulative & $47.383 \%$ & $80.580 \%$ \\
\hline
\end{tabular}


The results of the factor analysis based on the eigen values of more than 1 indicate that there are 2 components used. The first component has a contribution of $47,383 \%$ in explaining the total variation. The second component contributed $33,197 \%$ in explaining the total variation. So that these two components have a cumulative value of $80,580 \%$ in explaining the total variation.

The first component, based on the loading factor, 2 items have a coefficient of more than 0.50 , namely protection (0.924) and needs (0.913) and are named the need for protection factor. In the second component, based on factor loading, 2 items have a coefficient of more than 0.50 , namely health $(0.877)$ and preference (0.859). The results of this analysis conclude that the main explanations for students assessing the position of masks are: (1) it is a necessity during the pandemic and functions as self-protection when leaving the house, and (2) a feeling of liking for masks made of fabric to maintain personal health and other people. This is following Radika K Cahyadi (2020) opinions that the use of fabric masks is quite useful to minimize exposure to coronavirus droplets in carrying out daily activities in this new normal period, where several companies have begun to provide policies for their employees to be able to work in the office again.

\subsection{Mask Design Factors Analysis}

The mask design is described by 4 items, namely designed in a fashion, using bright colors, using cotton to make it more comfortable and there are additional mask accessories. Exploratory factor analysis is used to determine data structures that can explain considerations in assessing mask designs that are widely used by the community today. The application of this factor analysis requires dependencies between items that are determined using the Kaiser Myer Olkin (KMO) value and the Measure of Sampling Adequacy (MSA). Dependency is high if KMO and MSA are more than 0.50 .

Table 5. Dependency Description Between Mask Design Items

\begin{tabular}{ccl}
\hline Items & Mean & MSA \\
\hline Fashionable & 2.72 & 0.933 \\
\hline Colors & 3.13 & 0.588 \\
\hline Materials & 3.10 & 0.588 \\
\hline Accessories & 1.72 & 0.814 \\
\hline
\end{tabular}

$\mathrm{KMO}=0641$

The KMO value is 0.641 (more than 0.50) and the MSA is in the range 0.588-0.933 (more than 0.50), which explains that the item dependency requirements are acceptable. Furthermore, extraction is carried out into several components where the contribution of each attribute is explained by the size of the factor loading.

Table 6. Mask Design Items Extraction

\begin{tabular}{ccc}
\hline Items & \multicolumn{2}{c}{ Komponen } \\
\cline { 2 - 3 } & 1 & 2 \\
\hline Fashionable & 0.910 & 0.202 \\
\hline Colors & 0.888 & 0.280 \\
\hline Materials & 0.732 & 0.001 \\
\hline Accessories & 0.148 & 0.979 \\
\hline Eigen Value & 2.423 & 0.829 \\
\hline \% Total Variant & $60.580 \%$ & $20.719 \%$ \\
\hline \% Total Variant Cumulative & $60.580 \%$ & $81.299 \%$ \\
\hline
\end{tabular}

The results of the factor analysis explained that there were 2 components used. The first component contributed $60,580 \%$ in explaining the total variation. The second component has a contribution of $20,719 \%$ in explaining the total variation. So that these two components have a cumulative value of $81,299 \%$ in explaining the total variation.

The first component, based on the loading factor, 3 items have a coefficient of more than 0.50 , namely colors (0.910), materials (0.888), and fashionable (0.732) are the main display factors. The second component, based on factor loading, has 1 item having a coefficient of more than 0.50 , namely accessories (0.979). The 
results of this analysis conclude that the main explanations for students assessing the design are: (1) physically prioritizing colors, materials and looking fashionable, and (2) additional accessories to increase self-confidence and taste. Intifanny Amandara Putri said the same thing. (2020) which states that this fabric material is rated the best because of the material's ability to breathe. The ease of breathing when using a fabric mask is an important factor that will determine the comfort of its users. The comfort of the fabric mask material used will also affect how long the user wears a fabric mask, the problem of color is taste.

\section{Conclusion}

The results of the study proved that students/Millennials in the Covid-19 era against fabric masks (nonmedical) can be explained as follows:

1. Fabric masks (non-medical) are a necessity during a pandemic and function as personal protection when leaving the house.

2. Likes fabric masks (non-medical) made of fabric to maintain the health of oneself and others.

3. Liked the design of the mask more explained by the color factors, materials, and looks fashionable.

4. Liked there are additional accessories to increase confidence and taste.

\section{References}

Adhitya , D. (2007). Faktor -Faktor yang Berhubungan dengan Penggunaan Masker pada para Pekerja Pengamplasan di Perusahaan Meubel CV.Per mata7 Wonogiri. http://digilib.unnes.ac.id/gsdl/collect/skripsi/arc hives/HASH013d.dir/doc.pdf. Diakses tanggal 4 Juli 2020

Airy (2020).Pakai Masker untuk Jaga Kesehatan Selama Pandemi COVID-19 https://blog.airyrooms.com/info/himbauan-pakai-masker/. Diakses tanggal 12 Oktober 2020

Baharuddin. (2020). 2019-nCOV: COVID-19 Melindungi Diri Sendiri dengan Lebih Memahami Virus Corona. Jakarta: Rapha Publishing Fitrie Rahayu Sari, 2020. Efektivitas Penggunaan Masker Kain dalam Mencegah Covid-19 https:// primayahospital.com/paru/masker-kain-corona/ Diakses pada 12 Oktober 2020

Intifanny Amandara Putri. (2020). Fakta Tentang Masker Kain. https://www.bobobox.co.id/blog/faktatentang-masker-kain. Diakses pada 12 Oktober 2020

Nurul Sufitri, (2020). Cara Memakai dan Mencuci Masker Kain dengan Benar. https://www.nurulsufitri.com/2020/05/cara-tips-memakai-dan-mencuci-masker-kain-denganbenar.html . Diakses tanggal 12 Oktober 2020

Peraturan Menteri Kesehatan RI Nomor 9 Tahun 2020 Tentang Pedoman Pembatasan Sosial Berskala Besar dalam Rangka Percepatan Penanganan Corona Virus Disease 2019 (COVID-19). 3 April 2020. https://www.kemkes.go.id/resources/download/info-terkini/COVID19\%20dokumen\%20resmi/PMK-No.9-Th-2020_Pedoman-Pembatasan-Sosial-Berskala-Besar-DalamPenanganan-COVID-19.pdf. Diakses pada 1 Juni 2020

Radika K Cahyadi. (2020). New Normal di Kantor: Tata Cara Penggunaan Masker Kain. https:// www.gadjian.com/blog/2020/06/18/new-normal-kantor-cara-penggunaan-masker-kain/ Diakses: 12 Oktober 2020. 